\title{
Cutaneous Melanoma pT2 TNM Finding v6 and v7
}

National Cancer Institute

\section{Source}

National Cancer Institute. Cutaneous Melanoma pT2 TNM Finding v6 and v7. NCI

Thesaurus. Code C48845.

Cutaneous melanoma 1.01 to $2 \mathrm{~mm}$ in thickness, with or without ulceration. (from AJCC 6th and 7th Eds.) 